\title{
Solidarities, Fairness, and Economic Governance in Advanced Capitalism: The Cases of COVID-19 Responses in Germany and the United States
}

\author{
Achim Goerres \\ Professor of Empirical Political Science \\ Department of Political Science, University of \\ Duisburg-Essen, Germany \\ E-mail: Achim.Goerres@uni-due.de \\ www.achimgoerres.de
}

\author{
Mark I. Vail \\ Worrell Chair of Politics and International \\ Affairs \\ Department of Politics and International Affairs \\ Wake Forest University, USA \\ E-mail: vailm@wfu.edu \\ www.mivail.com
}

Paper to be presented at the 27th annual International Conference of Europeanists (virtual), 2125 June 2021. This version: 16 June 2021.

\begin{abstract}
This paper addresses the theoretical question of how competing models of social and economic solidarity shape patterns of economic governance in periods of economic crisis. Using the COVID-19 pandemic as a signal case, we seek to understand how changes in public opinion in response to similar social and economic shocks are informed by deeper ideational structures among citizens relating to their capacity for empathy, mutual support, and willingness to support and trust public policy interventions. Drawing on scholarly literatures related to moral economies and the social embeddedness of economic relationships, we undertake an empirical study of how the COVID-19 pandemic has shaped patterns of support for social and economic policies. We focus on Germany and the United States, countries with widely divergent modes of integration of capitalist markets and, therefore, potentially different levels of support for particular kinds of policy responses. We trace American and German policy responses since March 2020 across a number of domains, complemented by a systematic analysis of public opinion in the two countries, drawing from fifteen different sources of public-opinion data, in order to assess the pandemic's effects on public support for individualized and collectively-oriented policy responses.
\end{abstract}

Equal authors listed in alphabetical order. Both authors would like to thank Manuel Diaz Garcia for research assistance and the libraries of Tulane University and Wake Forest University for providing access to the Roper Archive and Gallup Analytics. AG would like to thank the European Research Council for funding this paper through the project POLITSOLID "Political Solidarities" accessible at https://bit.ly/politsolid 
How do competing models of social and economic solidarity and conceptions of economic fairness, in both elite and public opinion, shape public support for particular policy responses to periods of social and economic crisis? It is a truism that the COVID-19 pandemic has laid bare the limitations of models of economic governance across the advanced industrial world, exposing gaps in national systems of social protection (including monetary support and health and childcare services), the vulnerabilities of global supply chains and associated production models, and over-reliance on social benefits derived from labor-market relationships, and, in some countries, the effects of decades of underinvestment in educational and vocational-training systems. In so doing, it has both exposed and exacerbated glaring social and economic inequalities, leading some to characterize our era as a "new gilded age" (Pan 2020), in which accelerating accumulations of wealth and the top of the income distribution curve highlight the desperation of a growing underclass that enjoys neither stable employment, nor the luxury of remote work, nor significant savings enabling them to bridge the gap between jobs. In this sense, COVID-19 has merely brought into stark relief disquieting trends that long predate it, heightening the contradictions of late capitalism and discredited the long-held neoliberal nostrum that limited states and an expansive scope for market forces allow all boats to rise with the economic tide. Accordingly, it suggests with renewed urgency the need to rethink assumptions about economic governance inherited from the period of neoclassical consensus predating the 2008 financial crisis, while also revisiting the question of social solidarities as both reflections of conceptions of fairness starkly at odds with the world of atomized, rational, and procedurally equal individuals central to the neoclassical world view. ${ }^{1}$ Relatedly, the dire epidemiological and economic circumstances of the past eighteen months suggest a context within which new conceptions of economic citizenship may emerge, with changing understandings of mutual dependence among workers and the socially embedded character of work related to new sets of expectations and norms with respect to state involvement in the economy.

Our central research question is how periods of economic crisis reshape public understandings of economic and social solidarity and models of economic governance in advanced democracies. Using the COVID-19 pandemic as a signal case, we seek to understand how the acute uncertainties occasioned by the pandemic have highlighted and perhaps reinforced workers' capacity for empathy, mutual support, and willingness to sacrifice personal short-term interests for the sake of broader economic communities of which they are a part. Put somewhat differently, we hope to gain understanding of the extent to which private calculations of economic interests become embedded in, or even subsumed by, conceptions of common weal or shared public purpose. In this context, our analytical point of departure is that the economic trauma and social dislocation wrought by the pandemic have reshaped not only citizens' sense of interconnectedness and mutual dependence, but also the shared sense of public purpose of which the state is both the chief representative and the primary architect. In framing the question in this way, we draw implicit analogies with other kinds of national trauma, such as wars, which have historically transformed both patterns of social solidarity and trust and support for an expansion of government's role beyond the military arena, such as in the case of the creation of a

\footnotetext{
${ }^{1}$ For one compelling treatment of the discrediting of the neoliberal model and its replacement with a much more robust conception of economic governance, see (Fligstein and Vogel, 2020).
} 
comprehensive British welfare state in the aftermath of World War II. ${ }^{2}$ In the context of COVID19 , we investigate the extent to which the pandemic has fostered support for particular kinds of public policy interventions designed to sustain the economy and preserve the social fabric, and how these patterns of support, and the policy changes that they have underlain, vary crossnationally.

For the purposes of this paper, we focus on Germany and the United States, countries with widely divergent modes of integration of capitalist markets, differential levels of state capacity, distinctive systems of social protection, and starkly different industrial-relations institutions and relationships between capital and labor. Given these differences in traditions, prevailing norms, and institutions, we expect divergent patterns of social solidarities in the wake of the pandemic and, partially as a result, different policy responses and elite strategies for managing the crisis. We trace American and German policy responses since March 2020 (as well as EU policies that German elites have helped to craft), across a number of policy domains, including social protection (including job- and wage-protection schemes and transfer payments), financial assistance to firms, tax breaks for individuals and families, and macroeconomic interventions in fiscal policy, such as fiscal-stimulus initiatives. In our efforts to explain divergent outcomes in these areas, we also undertake systematic analysis of public opinion in Germany and the US about such initiatives and broader questions of fairness and solidarity, seeking to determine the extent to which German and American workers express a willingness for shared sacrifice and view their destinies as socially embedded and linked, or rather as atomized and individualistic. In so doing, we seek to connect societal capacities for solidarities to support for particular kinds of social and economic policies, thereby connecting the hypothesized German and American moral economies to the two countries' disparate policy trajectories.

While German and American policy responses have shared important elements, such as support for small business and credits for families with children, we argue that differing conceptions of public purpose, stemming from different levels of political trust and social cohesion, have led to distinctive patterns of public support for both government action in general and specific policy responses in particular. In both the US and Germany, the emotional trauma wrought by the pandemic, and public yearning for effective national responses, led to a marked increase in public trust of government and public officials. But the kinds of policies supported by the public varied significantly with levels of economic embeddedness and the degree of institutionalization of economic relationships. In the US, where such relationships are much more disembedded, public and elite support has coalesced behind particularistic benefits aimed at individuals and affected firms, and broad patterns of social trust and cohesion have been undermined by ideological battles over the appropriate role for the state. In Germany, by contrast, both the public and governing elites have tended to favor policy instruments that support strategically important groups in the political economy, such as skilled labor and firms in exportintensive industries, supported by a more developed conception of social purpose and mutual reliance.

In the next section of the paper, we develop our theoretical framework, which synthesizes sociological and historical conceptions of capitalism with "moral economy" approaches to understanding prevailing views of fairness and associated patterns of public opinion and support for state action in response to crises. We then provide a brief overview of German and American

2 As we discuss below, we also consider the extent to which reactions to the current pandemic can be compared to other similar contexts, such as the Spanish influenza pandemic of 1918-1919. 
policy responses to the pandemic, highlighting characteristic differences that, we contend, emerge from distinctive patterns of public opinion and associated conceptions of public purpose and state action. We then present our empirical data, connecting patterns of public opinion in the two countries to levels of social trust and support for particular types of policy interventions. We end with a brief conclusion in which we explore the theoretical significance of our findings and speculate about their implications for other historical periods of national trauma such as wars and other pandemics.

\section{Literature Review and Theoretical Framework}

Our paper investigates public and élite support for distinctive sets of social and economic policies in in the wake of the COVID-19 pandemic in Germany and the United States. This epidemiological and economic shock was, in equal measure, a social and political one, devastating advanced industrial economies and unsettling established paradigms and conventional wisdoms about the structural and desirable relationship between the state and the market in advanced capitalist societies.

In some respects, the trauma of COVID-19 paralleled that of the great influenza of 19181920, with 50-100 million dead worldwide and a disproportionately large impact in Europe. For instance, between September and November 1918, one million American troops fell ill in France (Martini et al. 2019). As across much of the world, the pandemic created social, economic and political challenges of a magnitude rarely seen in Germany and the United States. Given the early roots of the welfare state in Germany and the embryonic welfare structures in place at the time in the United States, a comparison between German and American reactions to the earlier pandemic and to COVID-19 initially seems a promising avenue for assessing the responses of different arrays of social and economic institutions to pandemics. However, two problems make it difficult to apply lessons from the earlier episode: in both countries, the influenza pandemic happened simultaneously with the end of World War I. It is thus very difficult to differentiate between dynamics that originated in the war and its immediate consequences of the influenza pandemic. Moreover, at that time, Germany experienced a paradigmatic change of political institutions, from a semi-democratic, authoritarian monarchy to a modern liberal, presidential democracy under the Weimar Republic. Furthermore, the influenza and its dramatic consequences were heavily censored in Germany and to a lesser extent in the US (Barry 2004). This not only makes it difficult to analyze the social and political reactions of the earlier pandemic, it also means that one of the causal chains that we assume for our two cases in 2020-21, namely citizens' reactions to information spread by the media, are quite difficult to assess in the earlier period.

Similarities to other pandemics notwithstanding, therefore, COVID-19 is to an important extent sui generis. The disruption to conventional assumptions about the structure and dynamics of capitalist political economies that it has occasioned presents an opportunity for researchers to analyze two sets of inter-related phenomena, both of which are partially constitutive of evolving conceptions of economic fairness: first, public support for social and economic policies designed to buffer workers from the effects of the shock and, by implication, for government more generally; and, second, norms relating to social solidarity and mutual support among citizens. Our theoretical point of departure is that the degree of social cohesion, involving horizontal bonds among citizens, shapes the character of citizens' attitudes toward and trust in the state, which is likely to both experience volatility and become politically salient in times of crisis, as in 
pandemics. In investigating patterns of change in both of these contexts, we seek to shed light on how periods of heightened economic uncertainty and trauma shape public conceptions of the structure and cohesiveness of social bonds and evolving models of economic governance and the role of the state. In so doing, we work to connect, theoretically and empirically, patterns of social cohesion and embeddedness, on the one hand, to the degree to which citizens share a conception of public purpose with governing elites.

\section{Comparative Macro-Level Approaches to Crises: How Political Systems React}

In developing our macro-level theoretical framework, we deploy and seek to build upon two central scholarly traditions and approaches, each stemming from a core set of theoretical concerns. The first entails the rich tradition of the comparative historical sociology of capitalism, exemplified, and in many respects inaugurated, in the work of Karl Polanyi (2001). Polanyi provides a deeply sociological conception of the emergence of capitalism in nineteenth-century England, demonstrating that the pursuit of a "market society" was both a deliberate construction of the state and constrained by limitations to the commodification of labor and the resultant resistance and mobilization of society in the wake of this pursuit. His account powerfully refutes the classical nostrums of the market as a natural outgrowth of human nature and of market structures as self-regulating. The implication, upon which Polanyi expounds in subsequent work, is that markets are contrived and constructed as institutionalized political projects and, as such, are merely one historically occurring basis of economic organization. For Polanyi, the socially embedded character of markets reflects a broader truth: that, in its unadulterated form, the logic of markets lies in tension with human society and is inconsistent with human life. Prior to the beginning of the process of market construction in the late seventeenth and eighteenth centuries, Polanyi shows, the evolution of economic life was informed by the much older norms of reciprocity and redistribution, whereby conceptions of equity and mutual reliance gave rise to economic relationships that were much less transactional and much more ensconced in organic social relationships than the "utopian" endeavor of market construction would acknowledge (Polanyi 1957). The implication is that patterns of economic change and adjustment to disruptive economic shocks are informed by deep structures of human solidarity, which both attenuate the imprint of market forces on those processes and inform the arrangements and norms that govern human responses to them and to the disruption that market capitalism can engender. This perspective also provides a theoretical construct through which to understand the character of social bonds and how they help to inform public views of the state and attendant policy expectations.

Though largely neglected by political scientists until the 1990s, Polanyi's emphasis upon the socially embedded character of capitalist economic relations provided a touchstone for subsequent critiques of the neoliberal, market-based orthodoxies of the past four decades. One scholar in this vein is Mark Granovetter, whose work brought similar insights to bear on more contemporary economic questions and debates over the appropriate and feasible scope of market arrangements in advanced industrial economies (Granovetter 1985). Granovetter argues that that even highly modern forms of economic life are deeply embedded in social structures and institutions. He argues that the level of economic embeddedness "has always been and continues to be more substantial than allowed by economists and formalists," who tend to reduce economic life to hypostatized images of atomized individuals (Granovetter, 1985: 483). Like Polanyi, economic sociologists like Granovetter locate the foundations of capitalist economies in the social relationships and institutions on which market transactions ultimately rely, relationships that 
nurture norms at odds with the transactional and atomized view of human beings central to classical and neoclassical models. This perspective suggests that in any capitalist economy, and particularly at moments of uncertainty, upheaval, and precariousness, such as during the COVID-19 pandemic, people are forced to seek support from non-market sources, whether that support be in the form of state-sponsored and -funded benefits or regulations, or from their fellow citizens, both directly within, and notionally beyond, their immediate familial and social circles. In both contexts, individuals seek support from and rely upon the collectivity, whether in the form of the commonwealth represented by the state or in more immediate and localized contexts. Here again, patterns of social cohesion and a shared sense of public purpose are inter-related.

The second body of scholarship that informs our broad analytical framework, also largely neglected by mainstream approaches to comparative politics and political economy, seeks to historicize and identify mechanisms behind the socially embedded economic structures and norms that govern workers' responses to disruptive economic change. The so-called "moraleconomy" literature, exemplified in the seminal work of E.P. Thompson (Thompson, 1964), grew out of the so-called "New Left" in Britain in the 1950s and 1960s, including Marxist scholars and public intellectuals such as Stuart Hall and Ralph Milliband, who contended that "culture and ideology had become as important as class in determining the course of history," in the words of Louis Menand (Menand 2021): 49). If Polanyi and Granovetter theorized the inherently social character of economic relationships, moral economists like Thompson investigate how such social contexts give rise to the norms that define the limits of transactional market relationship - what he calls the "cash nexus" - and give rise to the collective understandings of economic life that govern social and political responses to economic dislocation. Echoing Polanyi's point about the venerable pedigree of norms of reciprocity and redistribution, Thompson argues that "a moral economy . . . suppose[s] definite, and passionately held, notions of the common weal," "a consistent traditional view of social norms and obligations, of the proper economic functions of several parties within the community" (Thompson, 1971: 79). More recent work, which builds upon Thompson's work by applying his approach to more recent political-economic episodes, include Peter Swenson's (1989) work on Swedish and West German industrial relations in the 1980s and Charles Sabel's (1982) analysis of evolving "world views" among skilled and unskilled workers in France and Italy, with particular emphasis upon workers' "constant struggle to impose moral order on the economy." ${ }^{3}$

Focusing upon specific contexts in which "moral economies" are likely to be disrupted or to become politically operative, such scholarship provides powerful tools for understanding contemporary public and élite reactions to the devastation of the COVID-19 pandemic, and crossnational variation in patterns of reinvigorated public economic governance unmatched since the Great Depression. In similar fashion, we seek to understand how differing degrees of social embeddedness, and the horizontal ties - both actual and notional - that constitute them inform varying degrees of public trust in government, as well as related support for various kinds of policy responses. If, as we hypothesize, social cohesion and a shared sense of social identity, stemming from a more embedded model of capitalism, inform greater trust in government, a pattern that we observe in Germany, we also expect it to lead to more extensive and comprehensive policies that protect and subsidize social and economic groups and more cohesive approaches to public health, compared to countries that lack the same degree of a shared sense

\footnotetext{
${ }^{3}$ For prominent work in this tradition in comparative sociology, see especially the work of James C. Scott (e.g., (Scott 1976).
} 
of public purpose, such as the United States. This hypothesis finds indirect support in recent research that finds that countries and regions with greater degrees of social embeddedness and cohesion, which on study characterized as "civic capital," have displayed greater degrees of both cooperation among citizens in the wake of COVID-19 and more consistent support for publichealth measures (e.g., Durante et al., 2021).

\section{Micro-Level Approaches to the Nexus between Politics and Public Opinion: How the Publics React}

Unlike wars, whose emergence is often the product of longstanding international tensions, COVID-19 was largely unanticipated and made its impact felt almost instantaneously. Within weeks, the pandemic grew from a reported incident in China to a full-fledged global pandemic, a quintessential exogenous shock. Its sudden onset, and the resulting epistemological and narrative instability across both mass publics and political and economic elites and the broader social and political instability that it occasioned, provides potentially fertile ground on which to assess the effects of similar shocks on social cohesion and trust and attendant support for public interventions in social and economic policy and public health. Whereas our knowledge about the institutional system guides our theoretical framework about what governments did, we need to turn to public opinion research to understand how the public reacted in these two countries.

In theory, it is possible to differentiate between the reactions of the public to the pandemic itself and to policy responses taken to deal with it. This can be achieved by two means: by asking people what they think before governments have taken any measures in a relatively small window after the pandemic's onset by asking different questions, some about the pandemic itself, some about government measures. In practice, however, this proves to be more difficult. There is a significant time lag between sudden events and their effects on public polling. ${ }^{4}$

There is a disparate literature about crises and their effects on public opinion. It is helpful to focus attention on studies that look at crises that cannot be easily attributed broader problems with society, government or the economy, with much longer gestational periods and time horizons. Whereas, in such instances, citizens use their assessment of the perceived underlying problems in order to form their attitudes about the crisis (Goerres and Walter 2016), we should focus on public opinion reactions to pandemics and natural catastrophes and, to a lesser extent, wars, the closest obvious analog.

There is robust evidence about a unifying effect of external shocks in support of the executive and incumbent governments and administrations. In the United States, for example. such "rally" effects can be seen after military conflicts, with the necessary condition of some media attention to the topic as an intermediary variable. The micro-level mechanism seems to be that those who are ambivalent about the executive or government tend to favor the government (Baker and Oneal 2001; Baum 2002). Elite criticism of government immediately after the onset of the crisis is less prevalent in the media (Groeling and Baum 2008). Citizens perceive a stronger elite consensus in such contexts and adjust their attitudes accordingly.

The individual reactions that lead to such effects are driven by powerful emotions. Threats trigger anxiety and the desire for security, which citizens often seek from public officials and

\footnotetext{
${ }^{4}$ As a result, we are constrained to some extent by the timing of polling efforts and their relationship to government actions, such as executive orders introducing physical distancing measures, which were introduced within days.
} 
institutions. There are various psychological theories based upon the notion that humans seek a world that is predictable and secure (Lambert, Schott, and Scherer 2011). Although military conflicts are the most-studied trigger of a rally-around-the-flag effect, such studies also identify the importance of affirming in-group memberships in response to perceptions of threats from outgroups. The effects of such dynamics extend beyond public opinion about government responses to crises to social behavior. Winkler, for example, shows that disasters strengthen adherence to social norms by an average of 11\% (Winkler, Max 2020). Going beyond this initial observation, he explains that shared collective experience of disaster strengthens group cohesion. Altruism with respect to one's in-group seems to be a close partner of conflict and catastrophe (Bowles 2008). These reactions essentially stem from human nature, and we should expect them to play out in any political system, with real limitations to the effects of behaviors shaped by nationally distinctive institutions.

Hypotheses

Drawing from these theoretical frameworks, we anchor our empirical study in a series of hypotheses:

Hypothesis \#1: The onset of pandemics will increase support for incumbents and political trust in government in both countries in the short run.

Wars have been shown to create prosocial behavior at the individual level (Bauer et al. 2016) and to encourage burden-sharing and institution-building at the collective level (Obinger and Petersen 2017). The collective experience of hardship during war seems to lead to a logic of "we share the burden, we share resources" (see Titmuss 2019: chap. 4). Covid-19 was not a war, but it had some characteristics that remind us of war experiences. For one, it was impossible not to be directly affected by COVID-19 in one's everyday life. It was health-threatening and deadly for a substantial group with unknown consequences for long-term health. Like wars, it affected the economy and thus the lives of many indirectly as well. Prosocial behavior by more people is a plausible expectation, because the economic devastation wrought by the pandemic far exceeded the capacity of individuals or even significant social groups to manage. The traumatic experience of COVID-19 might also lead to altered preferences and thus a higher level of prosociality. Prosocial behavior is also likely to play out by means of attitudinal change of social trust.

Hypothesis \#2: Social trust will increase in both countries in the short run.

As in the case of in wars, citizens will support major government interventions related to health policy, as in the case of economic policy. It would thus be plausible to expect that citizens would grow accustomed to more government activity though that experience. It would be reasonable to expect that this effect would be more visible in the United States where the federal government is fragmented and baseline state capacity is weaker than in Germany. However, it remains unclear whether this shift in attitudes would be related primarily to the scope of government or, rather, to the intensity of government activities.

Hypothesis \#3: With respect to social and economic policy, we would expect path-dependence and cross-national policy divergence, with increased support for typical highly individualized provisions in the US, in contrast to support for more collectively- or group-oriented policies in Germany. 
Given the magnitude of the pandemic's shock to the two societies, it is reasonable to expect significant change in the policy priorities of their populations. Obviously, COVID-19 increased the salience of some issues that should be reflected in public opinion data. It is relatively trivial to expect that health policy issues will become more important in such a context. It was in people's self-interest to prepare themselves for the actual danger of infection and the related need for medical care. However, the two countries differ massively in the ways in which its healthcare systems are organized, a fact which provides reasons to expect different sets of expectations across the two countries. In Germany, coverage of health insurance is quasi-universal, with benefits funded and managed by shared contributions and administrative tasks between worker and employer representatives. The public hospital system is quite robust, and public-health infrastructure is relatively well developed. In the United States, by contrast, despite the expansion of coverage resulting from the Affordable Care Act, coverage is spotty and incomplete, benefit terms are much less generous, with patients often forced to pay significant out-of-pocket costs in the form of co-payments and co-insurance, with the result that health-care costs are one of the most common reasons for personal bankruptcies in the US. Public hospitals are also fragmented and uneven in terms of geographical coverage, and public health infrastructure is very underdeveloped underfunded, with widely varying capacities across states.

Moreover, unemployment as a problem should be more salient in people's minds. However, here too, the two countries differ massively in the ways in which unemployment protection is organized. In Germany, normal unemployment insurance pays up to $67 \%$ of a worker's previous wage, with benefit duration scaled by age and time of employment but typically lasting at least a year. Thereafter, the less-generous "Hartz IV" social-assistance benefit, the result of significant reforms undertaken by the administration of Social Democratic Chancellor Gerhard Schröder in the early 2000s, kicks in (Vail 2010). In the United States, by sharp contrast, unemployment insurance is limited a few hundred dollars per week, varying significantly by state. Whereas German workers and employers view unemployment insurance as a Bismarckian benefit paid for through contributions over time, in the US the benefit is heavily stigmatized and is contingent upon often-onerous job-search, reporting, and monitoring requirements designed to discourage eligible workers from obtaining the benefit.

The economic dislocation resulting from the pandemic leads one to expect that the problem of social inequality will become more prominent in people's minds. The pandemic was much harder on people who had fewer assets, could not work remotely, who lived in more constrained living circumstances, and who had care responsibilities for children or dependent adults. Under such circumstances, it is reasonable to expect an increase in the salience of economic inequality, but it is less clear how citizens socialized in these two systems would interpret and respond to it. Traditionally, the American public is much more tolerant of social inequality than the German public. Bénabou and Tirole (2006) explain this difference as an ultimately cultural difference related to the prevalence of the belief that individuals and their children can succeed economically. Given this, it is reasonable to expect that the salience of social inequality would rise in both countries, but that the demand for government action will be less in the US, because fewer citizens make the cognitive link between social problems and the government as a legitimate actor to counter them. This reasoning leads us to our final hypothesis.

Hypothesis \#4: Support for policy measures to reduce inequality will increase in Germany, but not in the US. 
Methods and data

\section{Research design and Data}

This is a comparative case study of how different political and social systems react to the same exogenously created crisis. One case is one country-crisis episode. We have two cases: the United States in the period 2019-21 and Germany in 2019-21. Within our cases, we concentrate on policy responses on the national level of government and on public opinion of the adult population as a whole and take the overtime variation within that period into consideration.

We use the Covid-19 pandemic as an exogenous shock to the two countries. The origin of the pandemic did not lie in either of these two countries. The reaction in the two countries as to what the governments did and the public thought is thus a reaction to that shock. The challenges in the two countries as to health, the labor market and the economy were very similar, but as we demonstrate, the reactions were quite different.

At first glance, the two countries' distinctive institutional landscapes would lead one to expect particular kinds of differences in their responses to this kind of exogenous shock I Although both are federal systems, with associated limitations on the capacity of the national state, the separation of powers in the American case, with a robust system of judicial review and a directly elected executive independent of the legislature, poses additional limitations on federal power. In Germany, by contrast, a parliamentary system in which the government emerges from and is responsible to a parliamentary majority, in which the purview of judicial review is more constrained, administrations confront fewer obstacles to aggressive responses to crises. In the US, moreover, where the past two years have witnessed perhaps unprecedented degrees of political polarization and vast partisan swings in the character and priorities of government, a casual observer would be justified in concluding that the weakness of shared public purpose would undermine a coherent policy response and lead to policy fragmentation and incoherence. Given that crises present challenges to which responses are chiefly crafted by the executive branch, a standard institutional account, focused on the constitutional distribution of authority, would lead one to expect a more rapid and robust response in the German case than in the American. As we discuss below, however, such a standard institutionalist framework fails to provide the analytical tools required to explain either the scope or the character of the German and American responses to COVID-19. Our data suggest a quite different story, one related to differences in the two countries' moral economies, ways in which economic institutions are socially embedded, and major differences between the two states' abilities to craft responses consistent with shared social purpose.

We can thus use these differences to explore to what extent the similar experiences and challenges were channeled differently in the two countries. Causally, we make use of the logic of within case designs, namely that Germany in February 2020 is very similar to Germany in January 2020 with the main differences that the first local infections of Covod-19 had taken place. The exogenous origin of the pandemic made the assumption very plausible that a temporal change can be attributed to Covid-19. However, we must be careful not to discount the difference between reaction to the pandemic and reactions to other reactions by other political actors. Thus, for instance, a rise in political trust after the onset of the pandemic can be a function of fear being more prevalent in the population or of appreciation of the measures that are taken.

We have collected an abundance of data. We have been able to make use of various policy collectefforts by other people (e.g., (Matthews 2021a), (McCollum 2020a), Süddeutsche Zeitung, 
2020, Bruegel, 2020) and secondary usage of existing analyses as to policy responses. In addition, this paper makes ample use of a variety of commercial and scientific public opinion data. Future iterations will provide exact references. All data are accessible to the public (Edelman Trust Barometer, More in Common, Politbarometer, Freiburger Politikpanel, Pew International), scientists (gesis internet panel) or through commercial database available to us (Kaiser Family Foundation, Gallup). Short notation in brackets gives a first hint to the source. The public opinion data differ widely in their definition of the target population (voters, residents, citizens), in their age definition (some start at 16, most at 18; some truncate at higher age), their sampling procedure (some use random sampling, some quota sampling, others convenience sampling) and their survey mode (phone, online).

\section{Empirical Analysis: Public Policy Responses to COVID-19 in Germany and the United States}

Like many advanced industrial countries, Germany and the United States rapidly deployed vast fiscal and administrative resources following the advent of the COVID-19 pandemic in March 2020 and have continued to provide economic support well into 2021. The measures involved, which varied from loan guarantees and payroll subsidies to businesses, to investments in public infrastructure, to direct assistance to families and individuals, were designed to meet both the unprecedented scale of the public-health challenges in both countries and the economic devastation that they left in their wake. We provide a timeline of major events in the pandemic and German and American policy initiatives in Figure 1 below. 


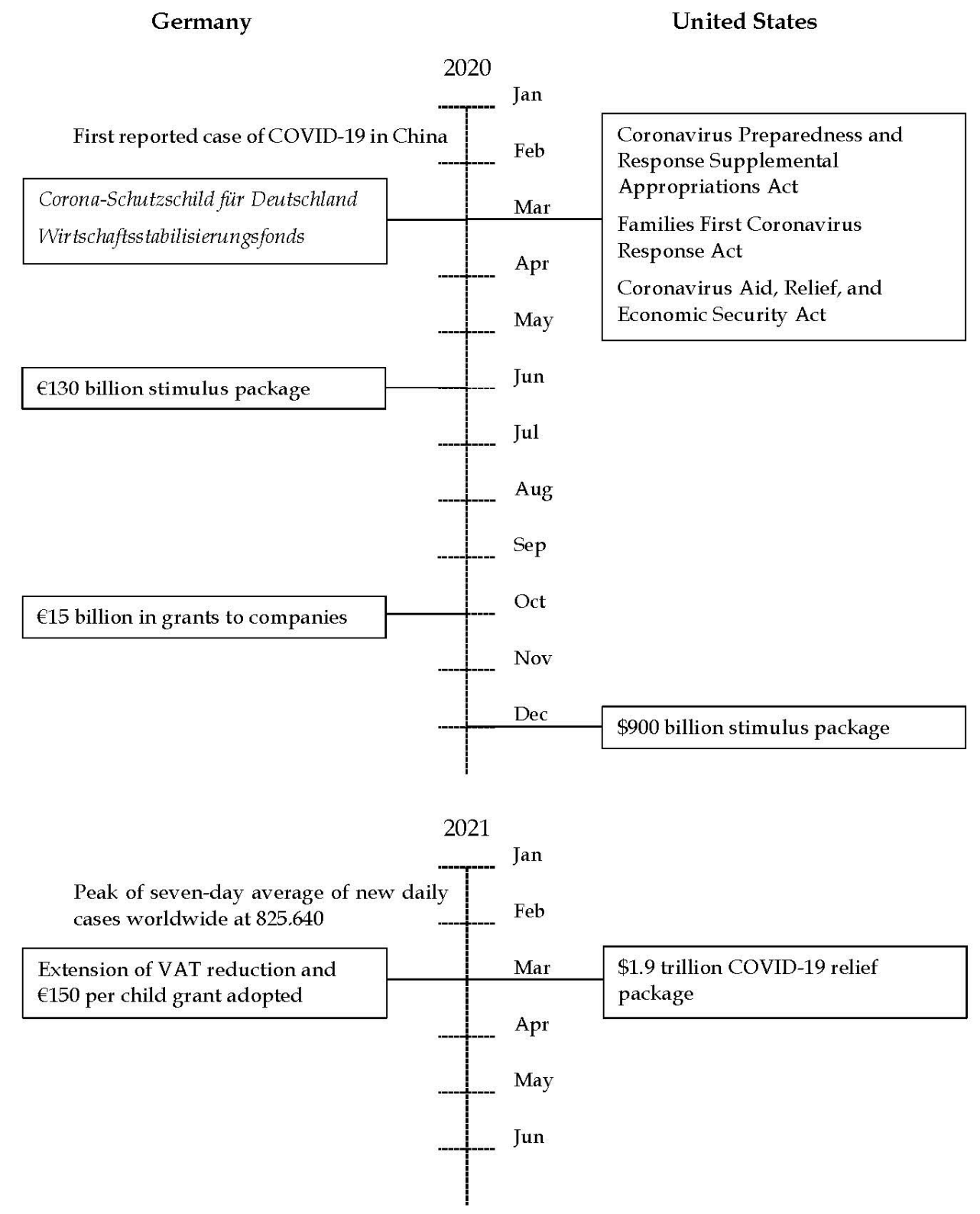

In Germany, the scale of the initiative echoed that of the response to reunification in 1990, when more than $€ 100$ billion was spent in its immediate aftermath and nearly $€ 2$ trillion over three decades but has been deployed over a much briefer time frame. ${ }^{5}$ In the US, the magnitude of the response is unmatched since the Great Depression, with some observers characterizing President Joe Biden as a modern incarnation of Franklin Roosevelt. Following the feckless and incompetent response of the Trump administration, the new administration has undertaken an astonishing deployment of state power and resources, shifting the prevailing policy-making

${ }^{5}$ For an overview of Germany's fiscal response to reunification, see (Vail 2018). 
paradigm away from the small-government and neoliberal orthodoxies that even the post-2008 Great Recession had been unable to displace (Alter 2021) (Carter 2021).

Although a combination of administrative and regulatory burdens, compounded by political errors by the government of Chancellor Angela Merkel, have plagued Germany's vaccination campaign, in comparison to a more effective and aggressive American response, both countries' fiscal- and economic-policy responses have been breathtakingly ambitious, paralleling those by several other advanced industrial countries. Including all discretionary spending until and including March 2021, the US has spent more than any other country as a share of the size of its economy (at $27.1 \%$ of GDP), while Germany's at $20.3 \%$ of GDP, is seventh largest in the world (Matthews 2021b). We provide a general overview of the character of the two countries' responses, along with characteristic policy responses, in Table 1 below.

Table 1: American and German Policy Responses to COVID-19

\begin{tabular}{|c|c|c|}
\hline Country & Key Substantive Focus & $\begin{array}{l}\text { Characteristic Policy } \\
\text { Initiatives }\end{array}$ \\
\hline United States & $\begin{array}{l}\begin{array}{l}\text { Fragmented investment in } \\
\text { public health }\end{array} \\
\begin{array}{l}\text { Supporting affected } \\
\text { businesses and individuals }\end{array}\end{array}$ & $\begin{array}{l}\text { Coronavirus Preparedness } \\
\text { and Response Supplemental } \\
\text { Appropriations Act } \\
\text { Paycheck Protection Program } \\
\text { Expansion of SNAP } \\
\text { Income-contingent direct } \\
\text { payments to individuals }\end{array}$ \\
\hline Germany & $\begin{array}{l}\text { Systematic investment in } \\
\text { public health } \\
\text { Subsidization of key groups } \\
\text { and social constituencies }\end{array}$ & $\begin{array}{l}\text { Corona-Schutzschild für } \\
\text { Deutschland } \\
\text { Expansion of Kurzarbeit } \\
\text { program } \\
\text { Soforthilfe for small businesses } \\
\text { Expansion of child benefits }\end{array}$ \\
\hline
\end{tabular}

Below, we outline these policy responses in both countries, providing an overview of discrete measures, their intended effects, and associated expenditures. In so doing, we pay particular attention to measures that have been crucial to each country's strategy for responding to the economic damage done by the pandemic and salient in public debates, thereby identifying those measures that have shaped public opinion and prevailing discourse surrounding the state's social and economic role and related conceptions of solidarity and mutual support among the two countries' citizenries. 
Germany's economic-policy strategy in the wake of COVID-19 has involved a combination of generous support for public-health initiative and an extension of both direct and indirect support to core constituencies of the Social Market Economy, including core industrial firms, small businesses, workers in key industries, and families. As the vice-chancellor and finance minister Olaf Scholz famously said on 13 March 2020: "This is the Bazooka with which we are doing what it takes"(Süddeutsche Zeitung, 2020), an image borrowed from the European Central Bank's handling of the 2008/9 financial crisis. In late March 2020, Merkel's government announced two major initiatives to support economic activity and buffer groups disproportionately affected by the mounting economic toll. The first, the so-called Corona-Schutzschild für Deutschland, or "Coronavirus Protective Shield for Germany," entailed three central initiatives. The first allocated a total of $€ 353.3$ billion (including $€ 156$ billion in new federal loans), including $€ 3.5$ billion for health-related measures such as personal protective equipment (PPE) for hospitals and investments in vaccine development. The second devoted $€ 55$ billion to remedy hospitals' and doctors' deteriorating finances and provide support to families, including subsidies for lost earnings resulting from closed schools and daycare centers and the associated need to care for children at home, and extended access to family allowances normally reserved to low-income families to workers with lost or reduced wages. The package's third major component involved $€ 50$ billion in so-called Soforthilfe ("Immediate Assistance") for small businesses, freelancers, and the self-employed(Bundesfinanzministerium, 2021a). The second major initiative, the Wirtschaftsstabilisierungsfonds, or Economic Stabilisation Fund, earmarked €891.7 billion for support for larger firms, particularly those with strategic economic importance. This measure included $€ 400$ billion in loan guarantees and $€ 100$ million for an assistance program for firms to be established within the Kreditanstalt für Wiederaufbau (KfW), a government-managed development bank. It also included various tax breaks and abatement for firms to assist with short-term balance-sheet difficulties (Bundesfinanzministerium, 2021a).

Not limited to firms and families, the German government has also provided extensive support for workers, particularly those in manufacturing and strategically important export sectors. The signal initiative in this category involves expenditures on so-called Kurzarbeitergeld, or "Short-time Work Program." Originally created in the aftermath of Germany reunification and resuscitated and extended in the wake of the post-2008 Great Recession, these schemes, which are funded jointly by the federal government and the Bundesagentur für Arbeit, or Federal Labor Office, allow at-risk workers to work reduced hours while receiving up to 90 percent of their previous pay, in the hopes of avoiding disruptive and costly layoffs. Between March and December 2020 alone, an additional $€ 23.5$ billion was spent on related programs(Bruegel 2020b). In a "Supplementary Budget" of $€ 122.5$ billion adopted in the same month, the government extended other forms of support to German workers, including an additional $€ 7.7$ billion for Arbeitslosengeld II, the second-tier assistance program for the unemployed.

In June 2020, the government adopted a second major stimulus package, in the amount of $€ 130$ billion, focused on tax relief to German firms and consumers and additional resources to assist families with children. In order to ease burdens on families while supporting consumption, VAT rates were cut from $19 \%$ to $16 \%$ for the standard rate and $7 \%$ to $5 \%$ for the reduced rate applied to necessities such as food in grocery stores. The initiative also provided an additional $€ 300$-per-child bonus payment to families with children and more than doubled the income-tax exemption for single parents, to $€ 4000$. The package also extended a number of tax breaks, including subsidies for municipalities suffering from declining tax revenue and a guarantee that combined social-security contributions (divided equally between workers and employers) would not exceed $40 \%$, in an effort to bolster workers' post-tax and -transfer incomes. For firms, it 
increased depreciation allowances and created more generous provisions for declaring losses from previous tax years. Finally, the measure made significant investments in renewable energy and infrastructure designed to bolster economic activity, including subsidies for purchases of electric vehicles, investments in battery-technology development, and a major effort to modernize Germany's aging fleets of buses and heavy commercial vehicles. In October, the package was supplemented with an additional $€ 15$ billion in grants to companies, and in March 2021 the reduction in VAT was extended and an additional $€ 150$ per child was paid to families with children (Bundesfinanzministerium, 2021b). Taken together, these initiatives provided urgently needed support for both investment and consumption and represented remarkably open-ended commitments for a country normally associated with excessive fiscal probity.

The United States: Investing in Public Health, Subsidizing Affected Industries and Businesses, and Expanding the Social Safety Net

In early 2020, against the backdrop of the Trump administration's incompetent and feckless response and politically motivated denial of the pandemic's severity, Congress moved in rare bipartisan fashion to respond aggressively to COVID-19's devastating impact on American public health and the economy. In March, three distinct but related measures were passed by Congress and signed into law by the president. The first, the "Coronavirus Preparedness and Response Supplemental Appropriations Act," devoted a modest $\$ 8.3$ billion to support public health, dedicated funds to vaccine research, funded broad public-health initiatives on the federal, state, and local levels, and purchased PPE for medical professionals (Breuninger 2020). The second, more ambitious package, the so-called "Families First Coronavirus Response Act," focused on the pandemic's economic effects on families and individuals. It devoted a total of $\$ 192$ billion to initiatives designed to subsidize workers in distress, including paid sick and medical leave for certain categories of businesses and significant subsidies to the Supplemental Nutrition Assistance Program (SNAP, colloquially knows as "Food Stamps"), temporarily increased the generosity of Medicaid and Medicare, the federal health-insurance programs for the poor and elderly, and subsidized existing unemployment-insurance benefits (Committee for a Responsible Federal Budget 2020).

The third, and much more extensive measure, dubbed the "Coronavirus Aid, Relief, and Economic Security Act," passed near the end of March, represented the most extensive (and expensive) crisis-related rescue and stimulus package since the New Deal. Costing \$2.2 trillion, the measure involved three distinctive areas of assistance. The first area entailed resources dedicated to supporting the incomes and livelihoods of individuals who had lost their jobs or been otherwise directly affected by the collapse in employment. One measure increased the generosity of unemployment insurance, providing an additional $\$ 600$ per week to increase the normally much-lower state benefits, while extending the length of eligibility. The second, broader in terms of its impact and designed both as a relief measure and as an effort to bolster aggregate demand, offered one-time relief payments of $\$ 1200$ per adult and $\$ 500$ per child, up to certain income thresholds, in the first of what would be several such initiatives in 2020 and 2021. In the same vein, the measure provided additional funds for SNAP and other forms of food assistance. The second set of measures was designed to support businesses directly affected by the collapse in demand and consumption, including $\$ 350$ billion for forgivable loans to small and mediumsized enterprises, along with other direct subsidies to smaller firms, and $\$ 58$ billion for airlines, which had seen air traffic more or less disappear in a matter of weeks. The third focused on hospitals, public health, and the healthcare industry, including funds for hospitals overwhelmed 
with COVID cases and forced to cancel lucrative elective surgeries as a result; additional funds for vaccine development, veterans' health, and the Centers for Disease Control and Prevention; and money for medical equipment and community health centers. In April, Congress passed an additional program, the Paycheck Protection Program, designed to bolster support to business, Modeled on European programs of wage and employment subsidies such as the German Kurzarbeit program, the law provided loans, forgivable under certain circumstances, to firms in exchange for their commitment to keep workers on their payroll. Although the program was beset with bureaucratic delays and some abuses, the initiative represented a true innovation in the US, where such programs had been previously unknown (McCollum 2020b).

As the pandemic dragged on, with a major spike in cases in the summer and the American death toll spiraling into the hundreds of thousands in the wake of lax public-health enforcement and compliance in many states, and following President Biden's electoral victory in November, Congress acted again, with an additional $\$ 900$ billion package. Modeled on the March law but smaller in scope, the initiative focused on extending or bolstering existing programs focused largely on supporting families' and individuals' incomes and the businesses where many of them worked or had worked. The measure provided additional income-contingent stimulus payments of $\$ 600$ per person, additional unemployment payments of $\$ 300$ per week, childcare and nutrition assistance, and emergency assistance to renters. On the business side, the law provided an additional \$248 billion for the Paycheck Protection Program, and generous funding for colleges and universities and the entertainment industry. Unlike the earlier law, the package devoted modest resources to infrastructure initiatives, including money to expand broadband internet access for families whose children were being educated at home, and $\$ 45$ billion for airlines, highway repairs, and public transportation. Despite some Republican reservations about the scale of the expenditures, the Senate was still in Republican hands, pending January special runoff elections for two Georgia Senate seats, and the party was reluctant to be blamed for inaction, particularly in the wake of President Trump's clear loss in the November election (Siegel, Stein, and DeBonis 2021).

Following two surprising Democratic victories in the Georgia Senate runoffs, which gave Democrats a Senate majority and unified political control, Congress and the new administration moved quickly to enact the most ambitious and generous package to date: $\$ 1.9$ trillion, compared to a $\$ 900$ billion package in December 2020. After weeks of often acrimonious debate and complaints from minority Republicans, Biden and the Democratic majority passed the $\$ 1.9$ trillion American Rescue Plan in March 2021 with no Republican support. This package was unprecedented in scale and scope, with generous extensions of previously-adopted measures as well as an array of new initiatives. Fulfilling a promise made by Democratic Senate candidates in Georgia and supported by the left wing of the party, the measure provided one-time, incomecontingent payments of $\$ 1400$ for each adult and child, while also extending the additional federal payments for unemployment insurance. Breaking with historical patterns of federal support for children, which had traditionally been provided through non-refundable tax credits rather than the direct payments common in many advanced industrial countries, the measure introduced six months of direct family allowances, scaled by family income, that were to be refundable beyond a family's tax liability. This paradigm-shifting initiative represented an unprecedented assumption of federal responsibility for supporting children. ${ }^{6}$ In addition to direct support for

\footnotetext{
6 Though temporary, leading Democrats have expressed the hope of making such an arrangement permanent.
} 
individuals and families, and in a provision derided by Republicans as a "blue-state bailout," the package extended $\$ 350$ billion to state and local governments, many of which had been forced to retrench services and lay off large numbers of public-sector workers in the face of collapsing tax revenue. The package also included a large array of measures of various kinds, including money for elementary and secondary schools and colleges and universities, restaurants, early childhood development programs, vaccine distribution, public transportation and infrastructure, as well as more than a half billion dollars for the Federal Emergency Management Association's (FEMA) Emergency Food and Shelter Program. All in all, the package represented both a strikingly ambitious response to the COVID calamity and an extension of the American safety net unknown since Lyndon Johnson's Great Society Program in the 1960s, with the creation of Medicare, the American health-insurance program for the elderly, and Medicaid, a federal-state program providing coverage to the poor and indigent elderly Proclaiming in the wake of the package's passage that "Help is here, and we will not stop working for you" (The White House 2021). Biden celebrated the initiative which, despite lockstep Republican opposition in Congress, enjoyed widespread public support, including by $41 \%$ of self-identifying Republicans or Republican leaners (Pew Research 2021).

\section{Empirical Analysis: Public Opinion Reactions}

Let us start by examining the potential rally-to-the-flag effects. Gallup runs a long-established global series asking for confidence in one's government.

Table 2: Confidence in national government, Germany and USA, 2019-2020

\begin{tabular}{|l|c|c|c|c|c|}
\hline $\begin{array}{l}\text { Confidence } \\
\text { government DE }\end{array}$ & national & 57 & +8 & 2020 & Source \\
$\begin{array}{l}\text { Confidence in } \\
\text { government USA }\end{array}$ & national & 36 & +10 & 46 & Gallup1 \\
\hline
\end{tabular}

Both countries reveal a clear jump in aggregate confidence in government. The German public's confidence rose by 8 percentage points from 57 to 65 percent. The American public's confidence rose by 10 percentage points from 36 to 46 percent. What is more, the high levels of confidence in both countries are exceptional in the long run, looking back to 2006 in this series. The second-highest confidence level in Germany was 63 \% in 2015. In the USA, only 2009 and 2006 witnessed higher levels at $50 \%$ and $56 \%$.

Table 3: Trust in national government, Germany and USA, 2019-2021

\begin{tabular}{|c|c|c|c|c|c|c|}
\hline & 2019 & & 2020 & & 2021 & Source \\
\hline $\begin{array}{l}\text { Trust in } \quad \text { national } \\
\text { government DE (5-9 on scale } \\
1-9)\end{array}$ & 44 & +19 & 63 & -4 & 59 & $\begin{array}{l}\text { Edelman1 } \\
\& 2\end{array}$ \\
\hline 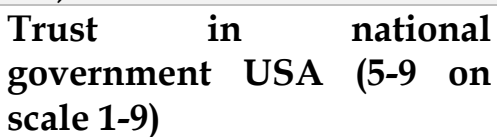 & 39 & +9 & 48 & -6 & 42 & $\begin{array}{l}\text { Edelman1 } \\
\& 2\end{array}$ \\
\hline
\end{tabular}


From another source (Edelman) and a comparable indicator (trust in government), we see a similar picture. We see a sizeable jump in trust in government by 19 percentage points in Germany and 9 points in the USA between 2019 and 2020 and then a receding level of trust in 2021. ${ }^{7}$ This increase in political trust after the onset of the pandemic has been demonstrated for other contexts in Western Europe (BOL et al. 2021; Oude Groeniger et al. 2021; SCHRAFF 2020).

Table 4: Approval of national leaders, Germany and USA, 2019-2020

\begin{tabular}{|l|l|l|l|l|}
\hline & $\mathbf{2 0 1 9}$ & & $\mathbf{2 0 2 0}$ & Source \\
\hline Approval of Merkel & 62 & +14 & 76 & Gallup \\
\hline Approval of Trump & 41 & +5 & 46 & Gallup \\
\hline
\end{tabular}

In both countries, there was an increase in approval of the national leader. The increase was much smaller in the United States ( $+5 \%$ ) compared to Germany (+14 \%).In sum, we thus see evidence I both countries for the rally-around-the-flag effects in public opinion. These materialized given the two different levels of general support or approval of national governments (higher in Germany than in the United States). The relative changes were upward in both countries between 2019 and 2020 with some evidence, where we already have it, of a slow decline in 2021. Despite the many institutional differences, we see similar changes as to the deeply human, emotional reactions in the public mind. This is also what we would expect to see according to Hypothesis\#1: human nature, the need to assurance and safety, dominates over institutionally embedded learning experiences.

In contrast to the emotional political effects, we cannot put forward any evidence yet for an increase in social trust (Hypothesis \#2). In order to get a sense of changed levels of prosociality, let us look at the percentages of residents who indicated to have helped a stranger recently. Here, we see that there is clear evidence against our expectations. The prevalence of helping strangers declined in both countries between 2019 and 2020 by 5 (DE) and 6 (USA) percentage points.

Table 5: Reported helping of a stranger, Germany and USA, 2019-20

\begin{tabular}{|l|c|c|c|c|}
\hline & $\mathbf{2 0 1 9}$ & & $\mathbf{2 0 2 0}$ & Source \\
\hline Helped a stranger DE & 45 & -5 & 40 & Gallup2 \\
\hline Helped a stranger USA & 64 & -6 & 58 & Gallup2 \\
\hline
\end{tabular}

Table 6: Social trust in Germany and USA, 2020

\begin{tabular}{|l|l|l|}
\hline Most people can be trusted DE & $\mathbf{2 0 2 0}$ & Source \\
\hline Most people can be trusted USA & 58 & Pew \\
\hline
\end{tabular}

\footnotetext{
7 Interestingly, the American public when asked in October (?) 2020 to estimate how trust in national government may have changed or stayed the same during the pandemic, only $5 \%$ said that it improved in juxtaposition to $54 \%$ who thought that it had gotten worse. In Germany, $19 \%$ thought it had gotten worse and $28 \%$ better.
} 
For social trust, we are still lacking data from before the crisis. We thus cannot access Hypothesis \#2 yet. In 2020, the levels of social trust were indistinguishable in the two countries at 59-59 percent 8

Furthermore, in Germany, there was strong evidence for support for status-maintaining policies as to positions on the labor market. By our own estimates from May/June 2020 data [gesis1], we see that four measures that directly support jobs had approval rates of $50 \%$ and more. Per-head payments for the public that would benefit everyone was only supported by $21 \%$ of the populace.

Table 7: Policy attitudes towards anti-Covid19 economic and social policies in Germany in May/June 2020

\begin{tabular}{|l|c|}
\hline Policy measure & $\begin{array}{c}\text { Support in the } \\
\text { adult population }\end{array}$ \\
\hline $\begin{array}{l}\text { Public financing of Kurzarbeit program with full reimbursement to } \\
\text { employers (including social contributions) }\end{array}$ & 71 \\
\hline Public financing of Kurzarbeit program, including for Mini-jobs & 67 \\
\hline $\begin{array}{l}\text { Increase in Kurzarbeit payments from } \mathbf{6 0} \% \text { to } \mathbf{8 0} \% \text { of the most recent } \\
\text { net wage }\end{array}$ & 81 \\
\hline $\begin{array}{l}\text { State subsidies for firms and sole proprietorships without obligation } \\
\text { of reimbursement }\end{array}$ & 68 \\
\hline $\begin{array}{l}\text { State subsidies for new hires, e.g., through reduction of social } \\
\text { contributions }\end{array}$ & 52 \\
\hline Public payments to all citizens & 21 \\
\hline
\end{tabular}

In another survey at the same time [Politb1], one-off payments for families with children also found a majority of $57 \%$. Note that there is not a single question about healthcare. This is because the near-universal healthcare system is in principle not controversial at all in Germany.

Turning now to the American public opinion data on specific policies, we notice immediately that health policy started off as the most salient policy area before the crisis and remained constantly so. Various surveys of the Kaiser Family Foundation reveal that the most important issue domain for the American public (as to their voting intentions) was health policy: $89 \%$ in February 2020 just before the pandemic, 85\% in May, 87 in September and $91 \%$ in October 2020 [Kaiser1-5]. In other words, the electoral salience of health policy was not really affected by the pandemic in the US because it had already been salient so much before. Therefore, it comes as no wonder that health policy changes suggested to fight the pandemic found broad majorities, too.

Table 8: Policy attitudes towards anti-COVID economic and social policies in the USA in July 2020

\begin{tabular}{|l|c|}
\hline Policy measure & $\begin{array}{c}\text { Support in the } \\
\text { adult population }\end{array}$ \\
\hline $\begin{array}{l}\text { increasing government financial assistance to help more } \\
\text { Americans who don't get health insurance through their jobs } \\
\text { purchase coverage top priority /important }\end{array}$ & 84 \\
\hline
\end{tabular}

8 In Regions with more civic culture (and higher levels of social trust), the lockdown measures created greater mobility reductions resulting in fewer deaths for Italy and Germany (Durante, Guiso, and Gulino 2021). This leads to a cross-sectional negative relationship between levels of social trust and exposure to Covid-19 risks. 


\begin{tabular}{|l|c|}
\hline $\begin{array}{l}\text { creating a government-administered health plan, sometimes called } \\
\text { a public option, that would compete with private health insurance } \\
\text { plans and be available to all Americans }\end{array}$ & 73 \\
\hline $\begin{array}{l}\text { increasing federal funding to state governments to help pay for } \\
\text { their Medicaid programs }\end{array}$ & 79 \\
\hline $\begin{array}{l}\text { providing government financial assistance for people who have } \\
\text { lost their jobs to purchase health insurance through their previous } \\
\text { employer, sometimes called COBRA insurance }\end{array}$ & 82 \\
\hline
\end{tabular}

[Kaiser3, July].

Let us finally move on to public views on inequality. Both countries, show high levels of worry for division. This is certainly not the same as worry about inequality. But still, for after the Covid crisis, $67 \%$ of Germans and $89 \%$ of Americans are worried about greater division in society [MiC1]. In Germany, there is evidence for an increase in support for a wealth tax for rich people with $€ 500,000$ in assets and more to combat the economic consequences of the pandemic. In May 2020 , there were already $45 \%$ in support rising to $64 \%$ in November 2020 [Jäckle1]. Such a wealth tax would obviously target the rich and benefit the non-rich. This rise in support is not mirrored in a rise for the solidarity contribution that has been levied since the 1990s in order to promote socio-economic inequality between East and West where support remains at merely $17 \%$ risen from $15 \%$. Among Americans, $67 \%$ supported a universal basic income for everyone for the course of the pandemic in July 2020 [Kais1], but there is no evidence for any drastic measures against inequality that would be sustained in the long run. This is, at least tentatively, supportive of our Hypothesis \#4.

In sum, we find first support for positive reactions along the logics of a rally-to-the-flag effect in both countries by increases in confidence and trust in government and approval of the national leaders. We still lack pre-crisis data for social trust and cannot asses our prediction there. The policy-specific reactions seem to be surprisingly predictable given the intensity and breadth of the pandemic in its consequences. Citizens seem to remain relatively unshaking in the ways in which they want governments to react. The German public seems to be supportive, as we would expect, of drastic policies to combat equality whereas in the US, we only see moderate evidence for time-boxed measures that would only be in place for the duration of the crisis.

\section{Conclusion: Social Embeddedness, Public Opinion, and Public Policy: The Lessons of COVID-19}

In this paper, we have traced German and American economic-policy responses to COVID-19 and sought to explain the two countries' varying policy responses as the products of differing moral economies and patterns of embeddedness of economic relationships in the two political economies. We have done so through a systematic investigation of shifts in public opinion on the two countries, drawing from a wide range of available data sources, with particular emphasis upon levels of public trust in government and support for varying kinds of policy initiatives. As elsewhere, COVID-19 represented an unanticipated, and in many respects unprecedented, social, economic, and political shock to the two countries, challenging established understandings of the relationship between state and market and destabilizing existing policy-making paradigms, as elites cast about for effective ways to respond to and manage the ensuing social and economic 
crisis. The trauma of the pandemic led to highly emotionally charged public responses, with significant increases in public trust in and reliance upon government in both countries. Borrowing an analogy with a concept usually invoked in wartime, this development reflects a significant "rally-around-the-flag" effect in both countries, an understandable reaction but one that was perhaps surprising in the United States, given the deep currents of public distrust and demonization of government that have prevailed since the 1980s. That said, the character of shifts in public opinion differed markedly in the two countries. In the United States, where economic relationships are much more disembedded and the moral economy more fragmented and individualistic, the public disproportionately supported individualized benefits and assistance to individualized firms directly affected by the pandemic's economic fallout, reflecting the logic of post-hoc, palliative care. In Germany, by contrast, where economic and labor-markets are more deeply embedded and institutionalized, and where workers and employers have traditionally shared a common, if sometimes contested, sense of public purpose, surveys reflected support for investments in existing collectivized labor-market institutions, with policies designed to avoid layoffs and preserve existing institutions. If the American response reflected a logic of post-hoc, palliative care, then, its German counterpart reflected one of preventative medicine combined with systemic support for established social and economic relationships.

Although our data are of recent vintage and the full scale of the effects of the pandemic on support for government and economic-policy interventions will likely take several years to unfold, our research does suggest several important lessons and implications for future research on the effects of cataclysmic shocks, such as pandemics and wars. First, despite widely varying baseline levels of support for government cross-nationally, such events tend to bolster public support for the kinds of collective responses that only states can provide. In ways that echo the venerable maxim that there are no atheists in foxholes, it would seem that there are relatively few libertarians or anarchists in pandemics. Second, the kinds of policy interventions supported by citizens may well parallel, and perhaps even reinforce, pre-existing levels of social embeddedness in the economy, with patterns of group-based solidarities, or their relative absence, acting as both outgrowths and reinforcements of existing institutions and established political and social practices. In this context, distinctive national moral economies and social and economic institutions are tightly linked, with exogenous shocks such as the COVID-19 pandemic revealing these underlying shared moral and conceptual frameworks in ways that are not reducible to simple institutional dynamics. Finally, in a more speculative vein, we suggest that the ways in which such underlying normative structures mediate between catastrophes and both public attitudes and social and economic arrangements may take years to unfold, much as the Black Death in the fourteenth century steadily eroded feudalism in ways that were far from obvious at the time. In future research, we hope to exploit the increasing availability of longitudinal publicopinion data related to COVID-19 to arrive and more systematic conclusions about the relationship between catastrophes and public attitudes. 


\section{References}

Alter, Jonathan. 2021. “Opinion | Can Biden Be Our F.D.R.?” The New York Times, April 12, 2021, sec. Opinion. https://www.nytimes.com/2021/04/12/opinion/biden-fdr-newdeal.html.

Baker, William D., and John R. Oneal. 2001. "Patriotism or Opinion Leadership?: The Nature and Origins of the 'Rally 'Round the Flag' Effect." Journal of Conflict Resolution 45 (5): 661-87. https://doi.org/10.1177/0022002701045005006.

Barry, John M. 2004. The Great Influenza: The Story of the Deadliest Pandemic in History. Penguin. https:// www.penguinrandomhouse.com/books/288950/the-great-influenza-by-johnm-barry/.

Bauer, Michal, Christopher Blattman, Julie Chytilová, Joseph Henrich, Edward Miguel, and Tamar Mitts. 2016. "Can War Foster Cooperation?" Journal of Economic Perspectives 30 (3): 249-74. https://doi.org/10.1257/jep.30.3.249.

Baum, Matthew A. 2002. "The Constituent Foundations of the Rally-Round-the-Flag Phenomenon." International Studies Quarterly 46 (2): 263-98. https://doi.org/10.1111/1468-2478.00232.

Bénabou, Roland, and Jean Tirole. 2006. "Belief in a Just World and Redistributive Politics." The $\begin{array}{llllll}\text { Quarterly Journal of } & \text { Economics } & 121 & \text { (2): }\end{array}$ https:/ / doi.org/10.1162/qjec.2006.121.2.699.

BOL, DAMIEN, MARCO GIANI, ANDRÉ BLAIS, and PETER JOHN LOEWEN. 2021. “The Effect of COVID-19 Lockdowns on Political Support: Some Good News for Democracy?" European Journal of Political Research 60 (2): 497-505. https://doi.org/10.1111/14756765.12401.

Bowles, Samuel. 2008. “Being Human: Conflict: Altruism's Midwife." Nature 456 (7220): 326-27. https://doi.org/10.1038/456326a.

Breuninger, Kevin. 2020. "Senate Passes \$8.3 Billion Emergency Coronavirus Package, Sending Bill to Trump's Desk." CNBC. March 2020. https:/ / www.cnbc.com/2020/03/05/ senate-passes-8point3-billion-coronavirus-billsending-it-to-trumps-desk.html.

Bruegel. 2020a. "The Fiscal Response to the Economic Fallout from the Coronavirus | Bruegel." 2020. https://www.bruegel.org/publications/datasets/covid-national-dataset/.

- - - 2020b. "The Fiscal Response to the Economic Fallout from the Coronavirus | Bruegel." 2020. https://www.bruegel.org/publications/datasets/covid-national-dataset/.

Bundesfinanzministerium. 2021a. "Emerging from the Crisis with Full Strength - Federal Ministry of Finance - <span>Issues</span>." Bundesministerium Der Finanzen. April 2021. https://www.bundesfinanzministerium.de/Content/EN/Standardartikel/Topics/Publ ic-Finances / Articles /2020-06-04-fiscal-package.html.

- - - 2021b. "Combating the Coronavirus: Germany Adopts the Largest Assistance Package in Its History - Federal Ministry of Finance - <span>Issues</span>." Bundesministerium Der Finanzen. April 1, 2021. https://www.bundesfinanzministerium.de/Content/EN/Standardartikel/Topics/Prio rity-Issues/Corona/2020-03-25-combating-the-corona-virus.html.

Carter, Zachary D. 2021. "Opinion | The Coronavirus Killed the Gospel of Small Government." The New York Times, March 11, 2021, sec. Opinion. https://www.nytimes.com/2021/03/11/opinion/coronavirus-economygovernment.html. 
Committee for a Responsible Federal Budget. 2020. "Families First Coronavirus Response Act Will Cost \$192 Billion." Committee for a Responsible Federal Budget. April 6, 2020. https:/ / www.crfb.org/blogs/families-first-coronavirus-response-act-will-cost-192billion.

Durante, Ruben, Luigi Guiso, and Giorgio Gulino. 2021. "Asocial Capital: Civic Culture and Social Distancing during COVID-19." Journal of Public Economics 194 (February): 104342. https:// doi.org/10.1016/j.jpubeco.2020.104342.

Goerres, Achim, and Stefanie Walter. 2016. "The Political Consequences of National Crisis Management: Micro-Level Evidence from German Voters during the 2008/09 Global Economic Crisis." German Politics $25 \quad$ (1): 131-53. https://doi.org/10.1080/09644008.2015.1134495.

Granovetter, Mark. 1985. "Economic Action and Social Structure: The Problem of Embeddedness." American Journal of Sociology 91 (3): 481-510. https://doi.org/10.1086/228311.

Groeling, Tim, and Matthew A. Baum. 2008. "Crossing the Water's Edge: Elite Rhetoric, Media Coverage, and the Rally-Round-the-Flag Phenomenon." The Journal of Politics 70 (4): 106585. https://doi.org/10.1017/S0022381608081061.

Lambert, Alan J., J. P. Schott, and Laura Scherer. 2011. “Threat, Politics, and Attitudes: Toward a Greater Understanding of Rally-'Round-the-Flag Effects." Current Directions in Psychological Science 20 (6): 343-48. https:/ / doi.org/10.1177/0963721411422060.

Martini, M, V Gazzaniga, N L Bragazzi, and I Barberis. 2019. “The Spanish Influenza Pandemic: A Lesson from History 100 Years after 1918." Journal of Preventive Medicine and Hygiene 60 (1): E64-67. https://doi.org/10.15167/2421-4248/jpmh2019.60.1.1205.

Matthews, Dylan. 2021a. "How the US Won the Economic Recovery." Vox. April 30, 2021. https:/ / www.vox.com/22348364/united-states-stimulus-covid-coronavirus.

- - - 2021b. "How the US Won the Economic Recovery." Vox. April 30, 2021. https://www.vox.com/22348364/united-states-stimulus-covid-coronavirus.

McCollum, Betty. 2020a. "H.R.266 - 116th Congress (2019-2020): Paycheck Protection Program and Health Care Enhancement Act." Webpage. 2019/2020. April 24, 2020. https://www.congress.gov/bill/116th-congress/house-bill/266.

- - - 2020b. "H.R.266 - 116th Congress (2019-2020): Paycheck Protection Program and Health Care Enhancement Act." Webpage. 2019/2020. April 24, 2020. https://www.congress.gov/bill/116th-congress/house-bill/266.

Menand, Louis. 2021. "The Making of the New Left." The New Yorker. March 22, 2021. https:// www.newyorker.com/ magazine/2021/03/22/the-making-of-the-new-left.

Neil Fligstein, Steven Vogel. 2020. "Political Economy After Neoliberalism." Text. Boston Review. October 5, 2020. http://bostonreview.net/class-inequality/neil-fligstein-steven-vogelpolitical-economy-after-neoliberalism.

Obinger, Herbert, and Klaus Petersen. 2017. "Mass Warfare and the Welfare State - Causal Mechanisms and Effects." British Journal of Political Science 47 (1): 203-27. https:/ / doi.org/10.1017/S0007123415000162.

Oude Groeniger, Joost, Kjell Noordzij, Jeroen van der Waal, and Willem de Koster. 2021. “Dutch COVID-19 Lockdown Measures Increased Trust in Government and Trust in Science: A Difference-in-Differences Analysis." Social Science \& Medicine 275 (April): 113819. https:// doi.org/10.1016/j.socscimed.2021.113819.

Pan, J. C. 2020. "Facing a Pandemic in the New Gilded Age." The New Republic, March 4, 2020. https://newrepublic.com/article/156744/facing-pandemic-new-gilded-age. 
Pew Research. 2021. “Most Americans Support \$1.9 Trillion COVID-19 Aid Package; Just a Third Say It Spends Too Much." Pew Research Center - U.S. Politics \& Policy (blog). March 9, 2021. https://www.pewresearch.org/politics/2021/03/09/broad-public-support-forcoronavirus-aid-package-just-a-third-say-it-spends-too-much/.

Polanyi, Karl. 1957. “The Economy as Instituted Process." In Trade and Markets in the Early Empires: Economies in History and Theory, edited by Karl Polanyi, Conrad M. Arensberg, and Harry M. Pearson. Glencoe, IL (USA): The Free Press.

- - - 2001. The Great Transformation: The Political and Economic Origns of Our Time. Boston: Beacon Press.

Sabel, Charles F. 1982. Work and Politics: The Division of Labor in Industry. Cambridge Studies in Modern Political Economies. Cambridge [Cambridgeshire]; New York: Cambridge University Press.

SCHRAFF, DOMINIK. 2020. "Political Trust during the Covid-19 Pandemic: Rally around the Flag or Lockdown Effects?" European Journal of Political Research n/a (n/a). https://doi.org/10.1111/1475-6765.12425.

Scott, James C. 1976. The Moral Economy of the Peasant: Rebellion and Subsistence in Southeast Asia. New Haven: Yale University Press.

Siegel, Rachel, Jeff Stein, and Mike DeBonis. 2021. “Here's What's in the $\$ 900$ Billion Stimulus Package." Washington Post, 2021. https://www.washingtonpost.com/business/2020/12/20/stimulus-package-details/.

Süddeutsche Zeitung,. 2020. "'Bazooka' gegen Corona: Bund errichtet Riesen-Schutzschild." Süddeutsche.de, March 13, 2020. https://www.sueddeutsche.de/wirtschaft/wirtschaftspolitik-bazooka-gegen-coronabund-errichtet-riesen-schutzschild-dpa.urn-newsml-dpa-com-20090101-200313-99318308.

Swenson, Peter. 1989. Fair Shares: Unions, Pay, and Politics in Sweden and West Germany. Cornell Studies in Political Economy. Ithaca: Cornell University Press.

The White House. 2021. "Remarks by President Biden on the American Rescue Plan." The White House. March 13, 2021. https://www.whitehouse.gov/briefing-room/speechesremarks/2021/03/12/ remarks-by-president-biden-on-the-american-rescue-plan-2/.

Thompson, E. P. (Edward Palmer). 1964. The Making of the English Working Class. New York: Pantheon Books.

Thompson, E.P. 1971. "The Moral Economy of the English Crowd."

Titmuss, (Richard M.). 2019. Essays on "The Welfare State." Bristol: Policy Press.

Vail, Mark I. 2010. Recasting Welfare Capitalism: Economic Adjustment in Contemporary France and Germany. Philadelphia: Temple University Press.

- - - 2018. Liberalism in Illiberal States: Ideas and Economic Adjustment in Contemporary Europe. Liberalism in Illiberal States. New York: Oxford University Press. https://oxford.universitypressscholarship.com/view/10.1093/oso/9780190683986.001. 0001/oso-9780190683986.

Winkler, Max. 2020. "Do Disasters Affect Adherence to Social Norms?" https://www.mxwinkler.com/research. 